\title{
Identification of the Transmitter and Receptor Mechanisms Responsible for REM Sleep Paralysis
}

\author{
Patricia L. Brooks ${ }^{1}$ and John H. Peever ${ }^{1,2}$ \\ Departments of ${ }^{1}$ Cell and Systems Biology and ${ }^{2}$ Physiology, Systems Neurobiology Laboratory, University of Toronto, Toronto, Ontario M5S 3G5, Canada
}

During REM sleep the CNS is intensely active, but the skeletal motor system is paradoxically forced into a state of muscle paralysis. The mechanisms that trigger REM sleep paralysis are a matter of intense debate. Two competing theories argue that it is caused by either active inhibition or reduced excitation of somatic motoneuron activity. Here, we identify the transmitter and receptor mechanisms that function to silence skeletal muscles during REM sleep. We used behavioral, electrophysiological, receptor pharmacology and neuroanatomical approaches to determine how trigeminal motoneurons and masseter muscles are switched off during REM sleep in rats. We show that a powerful GABA and glycine drive triggers REM paralysis by switching off motoneuron activity. This drive inhibits motoneurons by targeting both metabotropic $\mathrm{GABA}_{\mathrm{B}}$ and ionotropic $\mathrm{GABA}_{\mathrm{A}} /$ glycine receptors. REM paralysis is only reversed when motoneurons are cut off from $\mathrm{GABA}_{\mathrm{B}}, \mathrm{GABA}_{\mathrm{A}}$ and glycine receptor-mediated inhibition. Neither metabotropic nor ionotropic receptor mechanisms alone are sufficient for generating REM paralysis. These results demonstrate that multiple receptor mechanisms trigger REM sleep paralysis. Breakdown in normal REM inhibition may underlie common sleep motor pathologies such as REM sleep behavior disorder.

\section{Introduction}

Skeletal muscle paralysis (motor atonia) is a defining feature of normal REM sleep (Jouvet, 1967; Brooks and Peever, 2008a). It may function to prevent the dreaming brain from triggering unwanted and potentially dangerous sleep movements (Mahowald and Schenck, 2005; Brooks and Peever, 2011). Breakdown in REM sleep mechanisms is linked to common sleep disorders such as narcolepsy/cataplexy and REM sleep behavior disorder (RBD) (Mahowald and Schenck, 2005; Lu et al., 2006; Siegel, 2006; Burgess et al., 2010). The mechanisms responsible for REM sleep paralysis remain a matter of considerable debate (Brooks and Peever, 2008a; Chase, 2008).

Classic studies showed that skeletal motoneurons are hyperpolarized by glycine-mediated IPSPs during REM sleep (Nakamura et al., 1978; Soja et al., 1991), which led to the prevailing hypothesis that REM paralysis is single-handedly triggered by glycinergic inhibition of motoneurons (Chase et al., 1989; Chase and Morales, 2005). However, recent studies found that REM paralysis remained even after glycine receptors were blocked on motoneurons (Kubin et al., 1993; Morrison et al., 2003; Brooks and Peever, 2008b). Subsequently, it was hypothesized that REM paralysis is caused by loss of serotonergic and noradrenergic ex-

\footnotetext{
Received Jan. 24, 2012; revised April 25, 2012; accepted May 7, 2012.

Author contributions: P.L.B. and J.H.P. designed research; P.L.B. performed research;P.L.B. analyzed data; P.L.B. and J.H.P. wrote the paper.

This study was funded by the Canadian Institutes of Health Research and the National Science and Engineering Research Council of Canada. We thank members of our laboratory for reading this manuscript and providing helpful feedback. We also thank Clarissa Muere for her technical assistance with histology.

Correspondence should be addressed to Dr. John Peever, Systems Neurobiology Laboratory, Department of Cell and Systems Biology, University of Toronto, 25 Harbord Street, Toronto, Ontario, M5S 3G5, Canada. E-mail: John.Peever@utoronto.ca.

DOI:10.1523/JNEUROSCI.0482-12.2012

Copyright $\odot 2012$ the authors $\quad 0270-6474 / 12 / 329785-11 \$ 15.00 / 0$
}

citation of motoneurons (Fenik et al., 2005), but motor paralysis could not be overridden by direct chemical stimulation (e.g., glutamate, noradrenaline, serotonin) of motoneurons (Jelev et al., 2001; Chan et al., 2006; Burgess et al., 2008). These findings indicate that REM paralysis is triggered by a powerful, yet unidentified, inhibitory mechanism.

Several lines of evidence indicate that both metabotropic $\mathrm{GABA}_{\mathrm{B}}$ and ionotropic $\mathrm{GABA}_{\mathrm{A}} /$ glycine receptor-mediated inhibition of skeletal motoneurons underlies REM sleep atonia. First, brainstem circuits that control REM sleep contain GABA and glycine neurons that project to and synapse on motoneurons (Holstege, 1996; Rampon et al., 1996; Morales et al., 2006). Second, somatic motoneurons themselves express $G_{A B A}$, $\mathrm{GABA}_{\mathrm{A}}$ and glycine receptors, which when activated trigger cellular hyperpolarization (Lalley, 1986; Araki et al., 1988; Persohn et al., 1992; Okabe et al., 1994; Margeta-Mitrovic et al., 1999; O'Brien and Berger, 1999; Charles et al., 2003; O'Brien et al., 2004). Third, motoneurons are hyperpolarized by large-amplitude IPSPs during REM sleep (Nakamura et al., 1978). However, it is unknown whether REM sleep atonia is triggered by activation of both metabotropic $\mathrm{GABA}_{B}$ and ionotropic $\mathrm{GABA}_{\mathrm{A}}$ /glycine receptors.

Here, we aimed to identify the transmitter and receptor mechanisms responsible for REM sleep paralysis. We studied trigeminal motoneurons and the masseter muscles they innervate because this motor system experiences typical REM paralysis and contributes to sleep pathologies such as RBD (Schenck and Mahowald, 2002; Burgess et al., 2008; Brooks and Peever, 2011). We found that inactivation of both metabotropic $\mathrm{GABA}_{\mathrm{B}}$ and ionotropicGABA ${ }_{A} /$ glycine receptors prevented and indeed reversed REM paralysis. However, neither metabotropic nor ionotropic pathways alone are sufficient for inducing REM inhibition. REM 
paralysis is only reversed when motoneurons are cutoff from both metabotropic and ionotropic receptor-mediated inhibition. These results reshape our understanding of the transmitter and receptor mechanisms underlying REM sleep paralysis.

\section{Materials and Methods}

Animals

All procedures and experiments were approved by the University of Toronto's Animal Care Committee and were in accordance with the Canadian Council on Animal Care. Rats were housed individually and maintained on a 12:12 light/dark cycle (lights on at $0700 \mathrm{~h}$ ) and both food and water were available ad libitum. Procedures and experimental protocols are similar in nature to our previously published work (Brooks and Peever, 2008b; Burgess et al., 2008).

Surgical preparation for sleep and microdialysis studies

Studies were performed using male Sprague Dawley rats (average weight: $391 \pm 6 \mathrm{~g})$. To implant electroencephalographic (EEG) and electromyographic (EMG) electrodes and a microdialysis probe, sterile surgery was performed under anesthesia induced with intraperitoneal ketamine (85 $\mathrm{mg} / \mathrm{kg}$ ) and xylazine $(15 \mathrm{mg} / \mathrm{kg})$. Isoflurane $(0.5-2 \%)$ was also used to maintain depth of anesthesia, which was determined by absence of the pedal withdrawal and blink reflexes. Body temperature was monitored with a rectal probe (CWE) and maintained at $37 \pm 1{ }^{\circ} \mathrm{C}$.

Three insulated, multistranded stainless steel wire EMG electrodes (Cooner Wire) were implanted into the left and right masseter muscles. The wires were tunneled subcutaneously to an incision along the dorsal surface of the cranium. Three EMG electrode wires were also inserted into the nuchal muscle. Four stainless steel screws (JI Morris) attached to insulated 34 gauge wire (Cooner Wire) were implanted in the skull for recording cortical EEG (coordinates: $2 \mathrm{~mm}$ rostral and $2 \mathrm{~mm}$ to the left and right of bregma, and $3 \mathrm{~mm}$ caudal and $2 \mathrm{~mm}$ to the left and right of bregma).

To implant a microdialysis probe into the left trigeminal motor pool, a $\sim 2 \mathrm{~mm}$ burr hole was made at $9.4 \mathrm{~mm}$ caudal and $1.8 \mathrm{~mm}$ lateral to bregma (Paxinos and Watson, 1998). A microdialysis guide cannula (CMA) was then lowered $8.2 \mathrm{~mm}$ below the skull surface by stereotaxic manipulation. Dental cement (1234, Lang Dental) secured the cannula in place and after the cement was dry, EEG and EMG electrodes were connected to pins (Allied Electronics) and inserted into a custom-made head-plug (Allied Electronics) that was affixed to the skull with dental cement.

After surgery rats were given a subcutaneous injection of ketoprofen (5 $\mathrm{mg} / \mathrm{kg}$ ) and $5 \%$ dextrose in $0.9 \%$ saline and kept warm by a heating pad. They were also given a dietary supplement (Nutri-Cal) and soft food for the $2 \mathrm{~d}$ following surgery. Rats recovered for at least $7-10 \mathrm{~d}$ before experiments began.

\section{Experimental procedures for sleep and microdialysis studies}

Recording environment. During experiments, animals were housed in a Raturn system (BAS), which is a movement-responsive caging system eliminating the need for a commutator or liquid swivel. This caging system was housed inside a sound-attenuated, ventilated, and illuminated (lights on: 110 lux) chamber.

Electrophysiological recordings. EEG and EMG activities were recorded by attaching a lightweight cable to the plug on the rat's head, which was connected to a Super-Z head-stage amplifier and BMA-400 AC/DC Bioamplifier (CWE). EEG signals were amplified 1000 times and bandpass filtered between 1 and $100 \mathrm{~Hz}$. EMG signals were amplified between 500 and 1000 times and bandpass filtered between $30 \mathrm{~Hz}$ and $30 \mathrm{kHz}$. All electrophysiological signals were digitized at $500 \mathrm{~Hz}$ (Spike 2 Software, 1401 Interface, CED) and monitored and stored on a computer.

Microdialysis probes. A microdialysis probe was used to perfuse candidate drugs into the trigeminal motor pool. The microdialysis probe $(6 \mathrm{~K}$ Da cutoff; membrane length and diameter: $1 \mathrm{~mm}$ by $250 \mu \mathrm{M}, \mathrm{CMA}$ ) was placed into the left trigeminal nucleus. The microdialysis probe was connected to Teflon tubing (inner diameter $=0.1 \mathrm{~mm}$; Eicom), which was connected to a $1 \mathrm{ml}$ gastight syringe via a liquid switch (BAS). The probe was continuously perfused with filtered ( $0.2 \mu \mathrm{m}$ PVDF, Fisher Scientific) artificial CSF (aCSF: $125 \mathrm{~mm} \mathrm{NaCl}, 5 \mathrm{~mm} \mathrm{KCl}, 1.25 \mathrm{~mm} \mathrm{KH}_{2} \mathrm{PO}_{4}, 24 \mathrm{~mm}$ $\mathrm{NaHCO}_{3}, 2.5 \mathrm{~mm} \mathrm{CaCl}_{2}, 1.25 \mathrm{~mm} \mathrm{MgSO}_{2}, 20 \mathrm{~mm}$ D-glucose) at a flow rate of $2 \mu \mathrm{l} / \mathrm{min}$ using a syringe pump (BAS).

Drug preparation. All drugs were made immediately before each experiment and dissolved in aCSF. The following drugs were used to manipulate GABA and glycine receptors: CGP52432 (GABA ${ }_{\mathrm{B}}$ antagonist; FW: 420.27; Tocris Bioscience), baclofen $\left(\mathrm{GABA}_{\mathrm{B}}\right.$ agonist; FW: 213.66; Tocris Bioscience), bicuculline $\left(\mathrm{GABA}_{\mathrm{A}}\right.$ antagonist; $\mathrm{FW}$ : 435.87; Tocris Bioscience) and strychnine (glycine antagonist; FW: 370.9; SigmaAldrich). The AMPA receptor agonist ( $\alpha$-amino-3-hydroxy-5-methylisoxazole-4-propionic acid, FW: 186.17; Tocris Bioscience) was prepared in advance and stored in stock solutions at $-20^{\circ} \mathrm{C}$. All drugs were vortexed and filtered $(0.22 \mu \mathrm{m}$ PVDF, Fisher Scientific) before use.

\section{Experimental protocols}

Each experiment took $2 \mathrm{~d}$ to complete. On the first day at $0800-1000$ $\mathrm{h}$, animals were placed into a recording chamber and given at least $1 \mathrm{~h}$ to habituate before being connected to the recording tether. They were then given a minimum of $3 \mathrm{~h}$ to habituate to this before recordings began. Baseline recordings (without the microdialysis probe in place) were established on Day 1 of experiments, between 1300 and $1600 \mathrm{~h}$. The microdialysis probe was inserted at $1700 \mathrm{~h}$ and aCSF perfused throughout the night. Probes were inserted the night before experiments began because previous studies demonstrate that probe insertion induces spontaneous neurotransmitter release and local neuronal activation (Di Chiara, 1990; Kodama et al., 1998). On the second day of experimentation, candidate drug treatments (see below, Studies 1 and 2) were perfused in random order between 0800 1800 h. Because baseline (i.e., $1300-1600$ h) and drug treatment (i.e., 0800-1800 h) times were overlapping, potential effects of candidate drugs on REM sleep could be compared and determined. Each drug was applied onto the trigeminal nucleus for $2-4 \mathrm{~h}$, which typically allowed sufficient time for rats to transition through three complete sleep cycles (i.e., wake to NREM to REM sleep). An aCSF washout period of at least $2 \mathrm{~h}$ followed every drug treatment.

Study 1: Does $G A B A_{B}$ receptor activation at the trigeminal motor pool underlie REM sleep paralysis? We addressed this question in two ways. First, we activated $\mathrm{GABA}_{\mathrm{B}}$ receptors by perfusing baclofen $\left(\mathrm{GABA}_{\mathrm{B}}\right.$ receptor agonist) into the left trigeminal motor pool while monitoring left masseter muscle EMG activity. We did this to determine whether receptor activation could trigger motor paralysis. We used $0.5 \mathrm{~mm}$ baclofen because previous studies showed that this concentration can activate $\mathrm{GABA}_{\mathrm{B}}$ receptors both in vitro and in vivo (Okabe et al., 1994; Ouyang et al., 2007; Matsuki et al., 2009).

Next, we wanted to determine whether there is an endogenous $\mathrm{GABA}_{\mathrm{B}}$-mediated drive onto trigeminal motoneurons during either sleep or waking and whether removal of this drive in REM sleep could prevent REM paralysis of masseter muscle. We antagonized $\mathrm{GABA}_{\mathrm{B}}$ receptors in a dose-dependent manner by applying increasing concentrations of CGP52432 $(0.01 \mathrm{~mm}, 0.05 \mathrm{~mm}, 0.1 \mathrm{~mm}$, and $0.2 \mathrm{~mm})$ at the trigeminal motor pool.

Study 2: Is REM sleep paralysis triggered by activation of metabotropic $G A B A_{B}$ and ionotropic $G A B A_{A} /$ glycine receptors? We hypothesize that REM paralysis is caused by activation of both metabotropic $G_{A B A}$ and ionotropic $\mathrm{GABA}_{\mathrm{A}} /$ glycine receptors because (1) GABA and glycine are released onto motoneurons during REM sleep (Chase et al., 1989; Morrison et al., 2003; Brooks and Peever, 2008b), and (2) motoneurons express all three receptor types (Araki et al., 1988; Persohn et al., 1992; Margeta-Mitrovic et al., 1999). To test this hypothesis, we simultaneously antagonized $\mathrm{GABA}_{\mathrm{B}}, \mathrm{GABA}_{\mathrm{A}}$ and glycine receptors by perfusing $0.2 \mathrm{~mm}$ CGP52432, $0.1 \mathrm{~mm}$ bicuculline and $0.1 \mathrm{~mm}$ strychnine onto trigeminal motoneurons during sleep and waking. We used this concentration of CGP52432 because results from Study 1 showed it triggers potent increases in masseter tone when applied to motoneurons. This is supported by in vitro and in vivo studies showing $\mathrm{GABA}_{\mathrm{B}}$ receptors are effectively antagonized $0.2 \mathrm{~mm}$ CGP52432 (Westerink et al., 1996; Fedele et al., 1997; Chéry and De Koninck, 2000). We applied $0.1 \mathrm{~mm}$ bicuculline/strychnine because we previously showed that such concentrations antagonize $\mathrm{GABA}_{\mathrm{A}}$ and glycine receptor-mediated neurotransmission at 
a

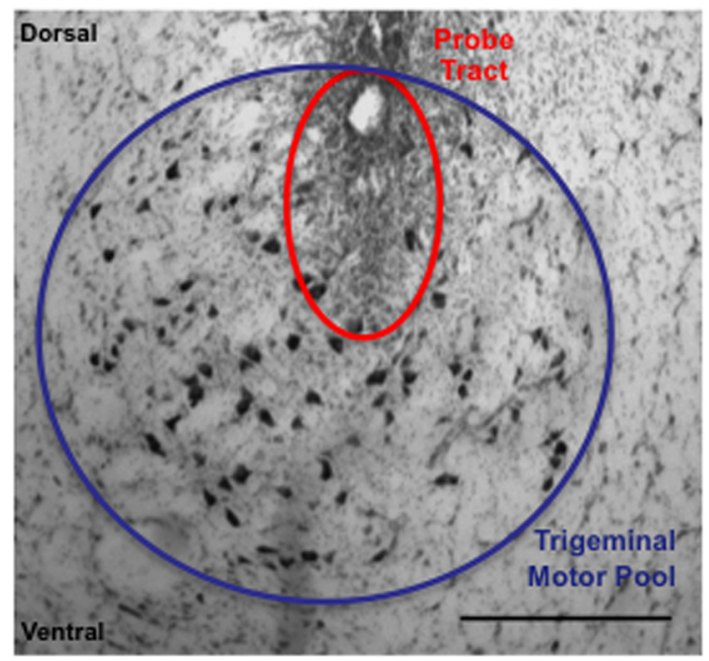

C
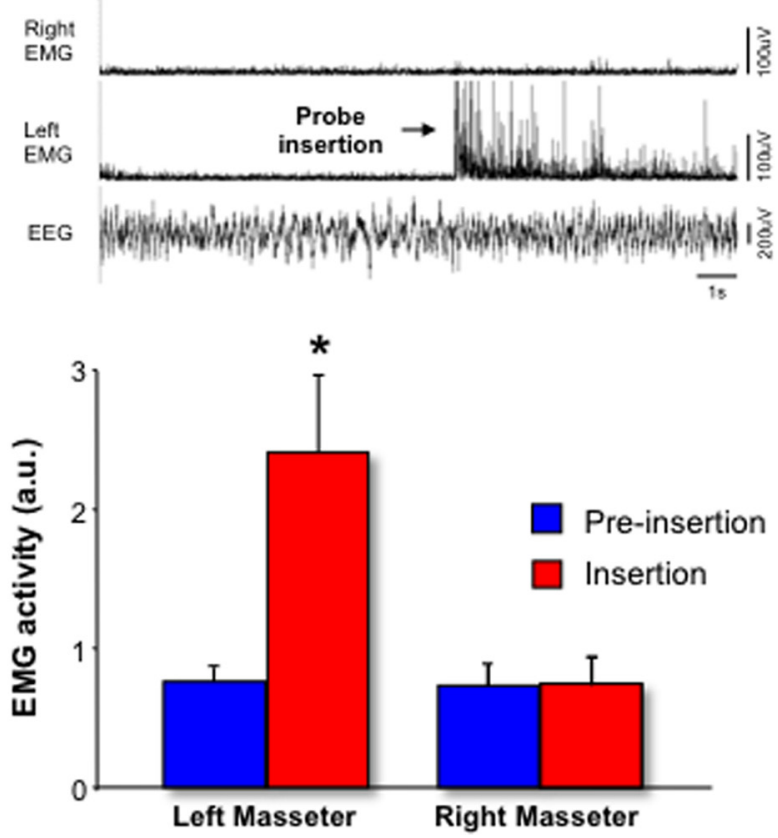

b

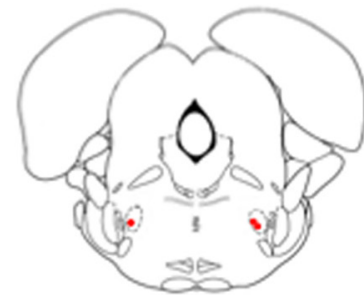

Bregma $-8.80 \mathrm{~mm}$

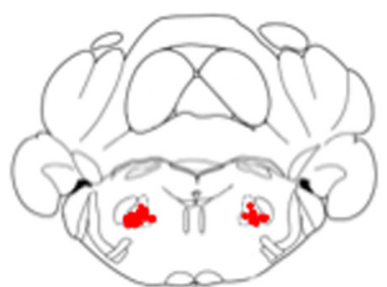

Bregma $-9.68 \mathrm{~mm}$

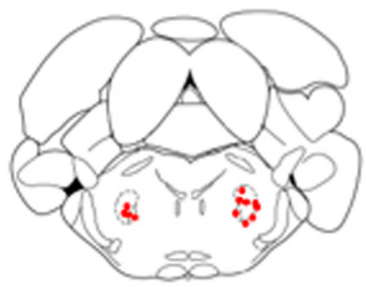

Bregma $-9.30 \mathrm{~mm}$

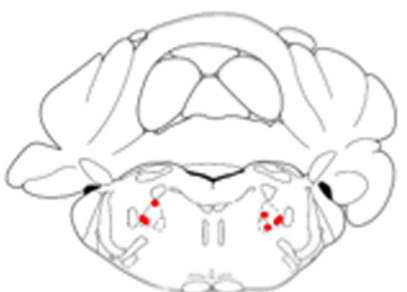

Bregma $-9.80 \mathrm{~mm}$ d
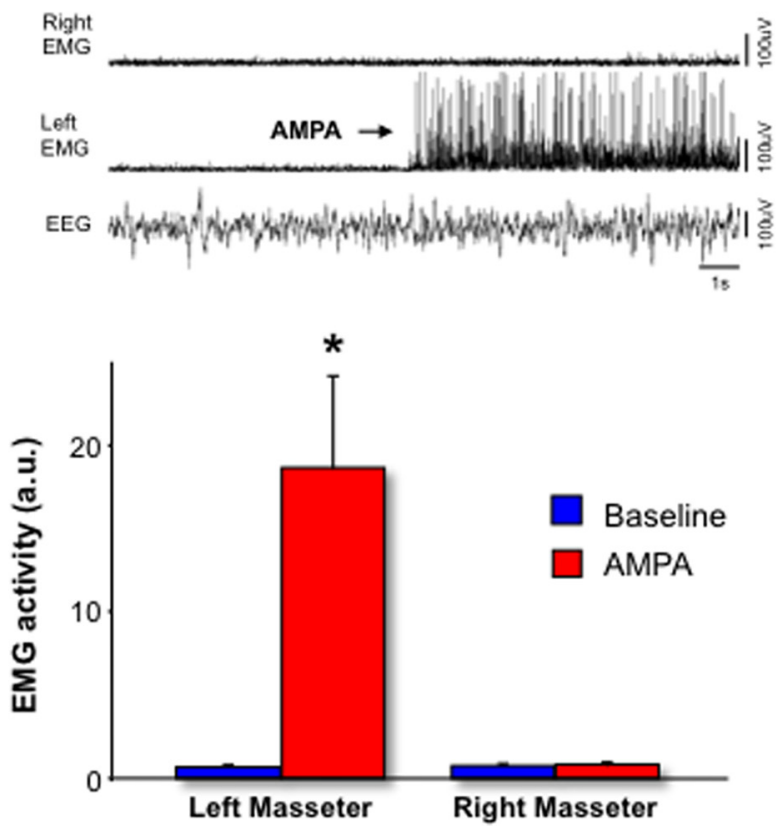

Figure 1. Drug interventions preferentially target trigeminal motoneurons. $\boldsymbol{a}$, A histological example showing the tip of a probe tract (red circle) in the trigeminal motor pool (blue circle). Scale bar, $500 \mu \mathrm{m} . \boldsymbol{b}$, Locations of the 31 probe tracts in the trigeminal motor pool plotted on standardized brain maps. Red dots represent probe tip locations in the trigeminal motor pool. Although probes were only placed in the left motor pool, we plotted probe locations in both left and right motor pools in this figure for the sake of visual clarity. $c$, EEG and EMG traces (top) and group data (bottom) showing that inserting a probe into the left trigeminal motor pool only increases left masseter muscle activity (left EMG), right masseter (right EMG) activity is unaffected. $\boldsymbol{d}$, EEG and EMG traces (top) and group data (bottom) showing that AMPA perfusion at the left motor pool only increases left masseter muscle activity. ${ }^{*} p<$ 0.05 . All values are mean \pm SEM.

the trigeminal motor pool (Morrison et al., 2003; Brooks and Peever, 2008 b).

Because we had concerns that drug perfusion (via microdialysis) for extended periods of time (i.e., 2-4 h) might spread to REM sleep circuits near the trigeminal motor pool or that inadequate receptor antagonism may not block GABA and glycine inhibition on motoneurons, we directly microinjected high concentrations of receptor antagonists $(0.3 \mathrm{~mm}$ strychnine/bicuculline and 0.6 mM CGP52432) at the trigeminal motor pool only during REM sleep ( $n=31$ rats).

Microinjections were performed by placing injection probes (i.e., CMA/11 microdialysis probes with dialysis membranes removed) into a guide cannula situated in the left trigeminal motor pool. A $1 \mu$ l Hamilton syringe was then attached to each probe by a $30 \mathrm{~cm}$ length of tubing and $0.2 \mu \mathrm{l}$ of a candidate drug was applied over a $15 \mathrm{~s}$ period. All injections were confined to individual REM sleep episodes with each injection beginning at the transitioned from NREM into REM sleep. Drug effects on masseter atonia were collected and analyzed only for the REM period in which receptor antagonists were applied onto trigeminal motoneurons. This approach enabled us to determine how rapid and focal antagonism

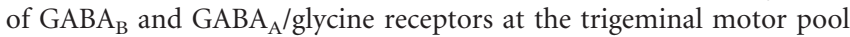
influences REM masseter atonia during a discrete REM episode.

\section{Verification of microdialysis probe location}

Two procedures were used to demonstrate that microdialysis probes were both functional and located in the left trigeminal motor pool. At the end of each experiment, $0.1 \mathrm{~mm}$ AMPA was perfused into the trigeminal nucleus. If the probe is functional and at the motor pool then glutamatergic activation of motoneurons should increase left masseter muscle 
tone. We also used postmortem histological analysis to demonstrate that microdialysis probe lesion sites were physically located in the left trigeminal nucleus.

\section{Histology}

Under deep anesthesia (ketamine: $85 \mathrm{mg} / \mathrm{kg}$ and xylazine: $15 \mathrm{mg} / \mathrm{kg}$, i.p.) rats were decapitated, brains removed and placed in chilled $4 \%$ paraformaldehyde (in $0.1 \mathrm{M}$ PBS) for $24 \mathrm{~h}$. Brains were cryoprotected in $30 \%$ sucrose (in $0.1 \mathrm{~m}$ PBS) for $48 \mathrm{~h}$; they were then frozen in dry ice and transversely sectioned in $40 \mu \mathrm{m}$ slices using a microtome (Leica). Brain sections were mounted, dried and stained with Neutral Red. Tissue sections were viewed using a light microscope (Olympus) and the location of probe lesion tracts were plotted on standardized brain maps (Paxinos and Watson, 1998).

\section{Data analysis}

Behavioral state. We classified 3 behavioral states. Waking (W) was characterized by highfrequency, low-voltage EEG signals coupled with high levels of EMG activity. NREM sleep was characterized by high-amplitude, lowfrequency EEG signals and minimal EMG activity. REM sleep was characterized by lowamplitude, high-frequency theta-like EEG activity and REM atonia interspersed by periodic muscle twitches. Sleep states were visually identified and analyzed in $5 \mathrm{~s}$ epochs using the Sleepscore v1.01 script (CED).

EMG analysis. Raw EMG signals were fullwave rectified, integrated and quantified in arbitrary units (a.u.). Average EMG activity for left and right masseter and neck muscle activity was quantified in $5 \mathrm{~s}$ epochs for each behavioral state. EMG activity was not analyzed during the first $30 \mathrm{~min}$ of drug perfusion because of the delivery latency from the syringe pump to the microdialysis probe. At least three episodes of each behavioral state (i.e., W, NREM, and REM) were analyzed for each experimental condition. In each rat, the average EMG activity was calculated for each behavioral state for each drug perfused into the trigeminal motor pool.

EMG analysis in REM sleep. REM sleep consists of both tonic and phasic motor events. The stereotypical periods of motor atonia occur during tonic REM sleep and the periodic muscle twitches that punctuate REM atonia occur during phasic REM sleep (i.e., during rapid eye-movements). Because the goal of this study was to determine the role for $\mathrm{GABA}_{\mathrm{B}}$ inhibition in REM motor control, we used a previously established method for identifying and quantifying the phasic (i.e., muscle twitches) and tonic (i.e., REM atonia) periods of REM sleep. In each rat, REM atonia and muscle twitches were quantified for each REM episode during the baseline condition and for each drug perfused into the trigeminal motor pool (Brooks and Peever, 2008b; Burgess et al., 2008).

EEG spectral analysis. EEG spectral analysis was calculated using fast Fourier transformation of each $5 \mathrm{~s}$ epoch, yielding a power spectra a
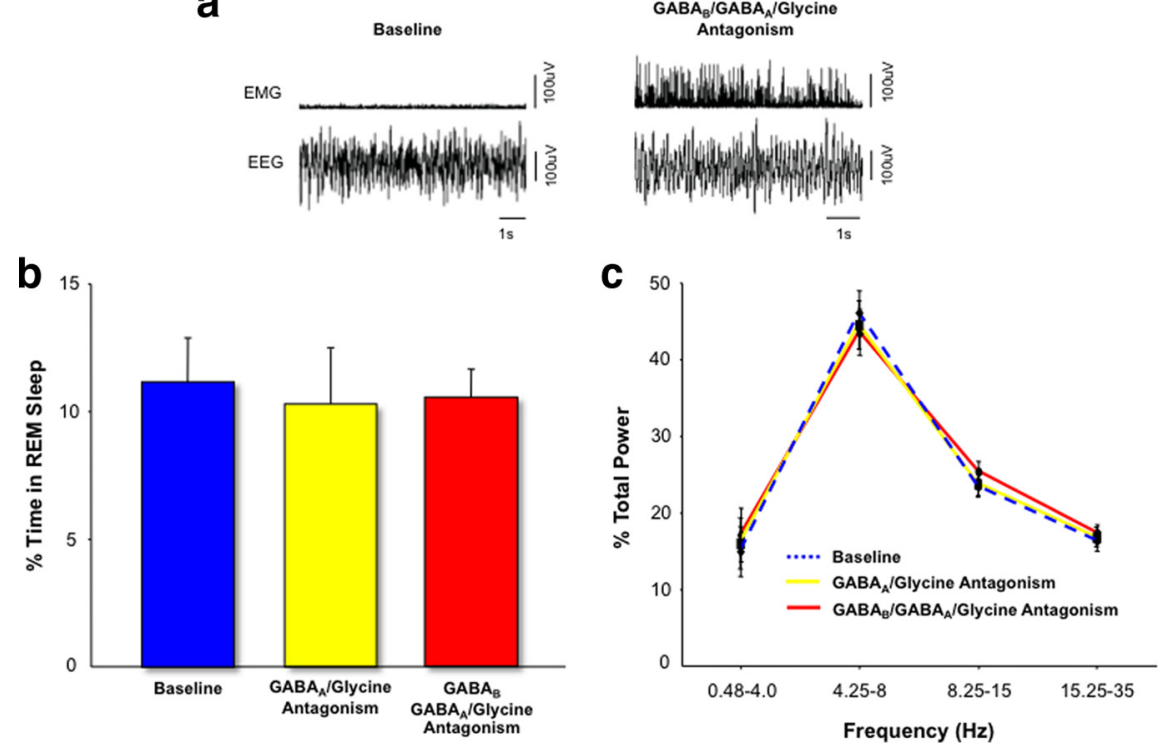

Figure 2. Drug manipulations do not affect REM-generating circuits. $\boldsymbol{a}$, REM sleep paralysis is abolished by preventing GABA and glycine receptor-mediated inhibition of trigeminal motoneurons. EEG and EMG traces (i.e., masseter muscle) showing that blockade of $\mathrm{GABA}_{B} / \mathrm{GABA}_{\mathrm{A}} /$ glycine receptors on trigeminal motoneurons reversed and prevented masseter REM sleep paralysis. Neither REM sleep amounts $(\boldsymbol{b})$ nor REM sleep EEG spectral power $(\boldsymbol{c})$ were affected when ionotropic $\mathrm{GABA}_{\mathrm{A}} / \mathrm{glycine}$ and metabotropic $\mathrm{GABA}_{\mathrm{B}}$ receptors were antagonized at the trigeminal motor pool. Perfusion of either $0.1 \mathrm{~mm}$ bicuculline/strychnine or $0.2 \mathrm{~mm}$ CGP52432 and $0.1 \mathrm{~mm}$ strychnine/bicuculline at the trigeminal nucleus had no affects on REM sleep amounts or EEG power, indicating that applied drugs did not spread to and influence REM-regulating circuits in the nearby sublaterodorsal nucleus. However, metabotropic $\mathrm{GABA}_{B}$ and ionotropic $\mathrm{GABA}_{\mathrm{A}} /$ glycine receptor antagonism on trigeminal motoneurons had profound affects on masseter tone during REM sleep $(\boldsymbol{a})$. All values are mean $\pm \mathrm{SEM}$.

a

Baseline
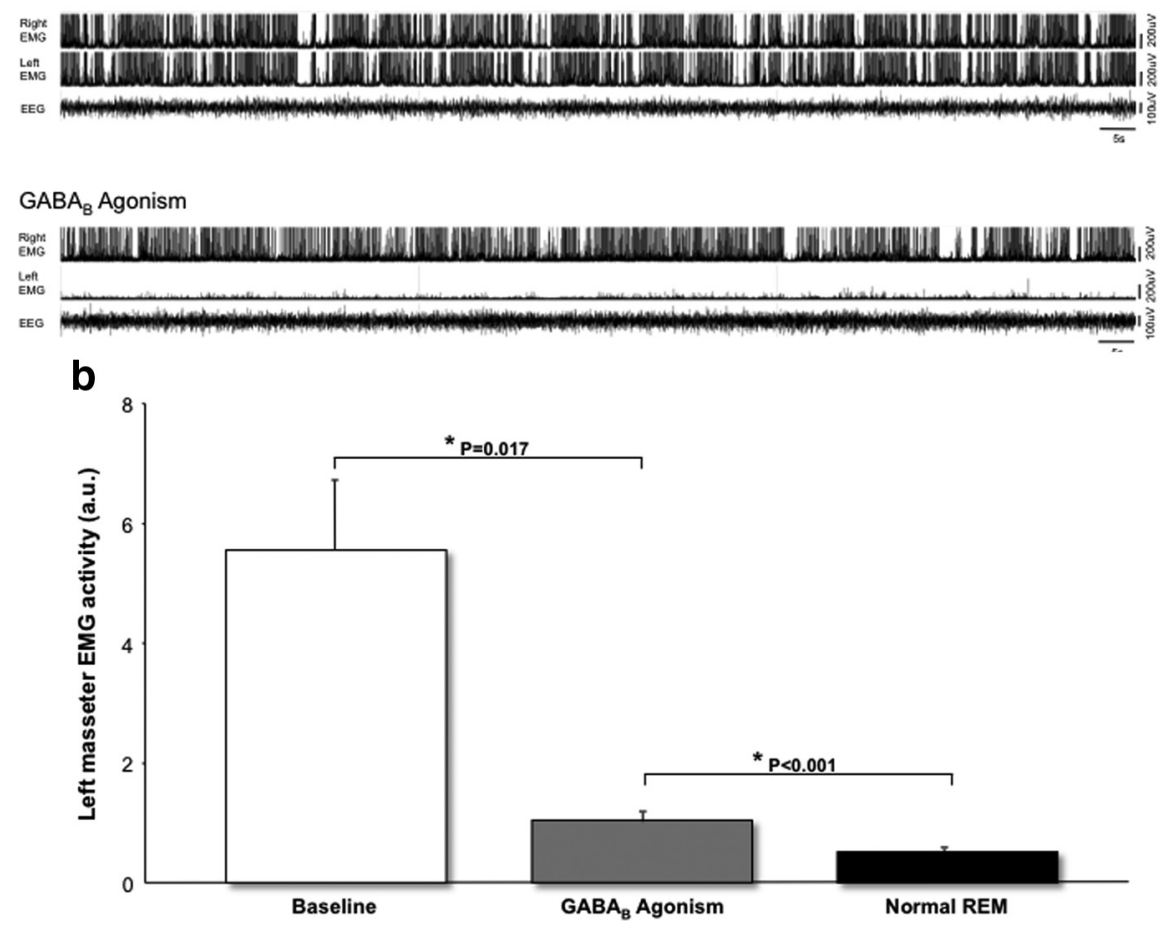

Figure 3. $G A B A_{B}$ receptor activation on trigeminal motoneurons reduces masseter tone, but does not trigger muscle paralysis. $\boldsymbol{a}$, EEG and EMG traces showing that $\mathrm{GABA}_{\mathrm{B}}$ receptor agonism by baclofen $(0.5 \mathrm{~mm})$ perfusion at the left trigeminal motor pool markedly reduces (compared with baseline) left masseter tone (left EMG) during waking. Right masseter muscle tone is unaffected. $\boldsymbol{b}$, Group data $\left(n=5\right.$ ) showing that compared with baseline baclofen-induced activation of $\mathrm{GABA}_{\mathrm{B}}$ receptors on trigeminal motoneurons reduces waking masseter tone. However, this intervention does not reduce waking masseter tone to normal REM sleep levels. All values are mean \pm SEM. 
a

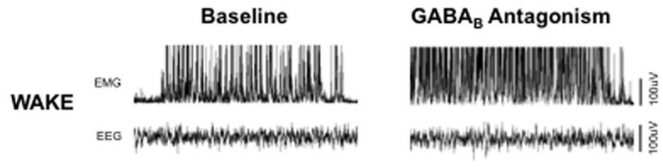

NREM

EMS

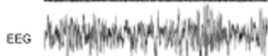
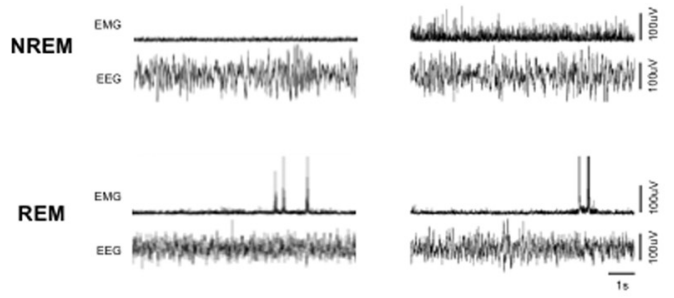

b

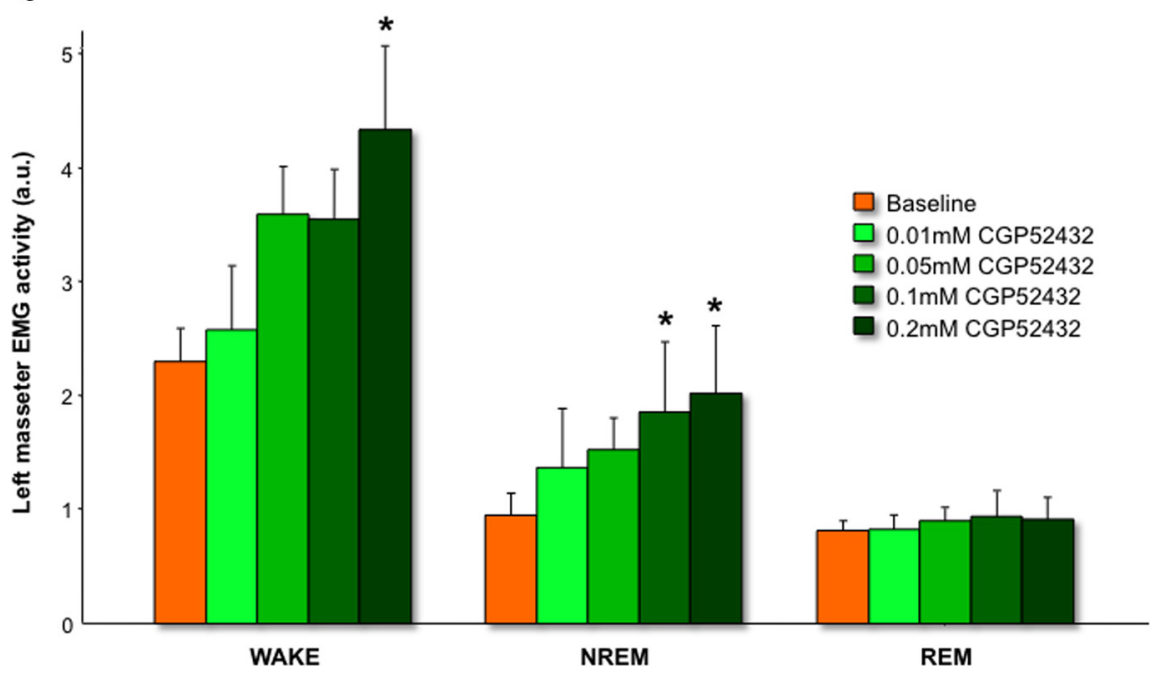

Figure 4. $\mathrm{GABA}_{\mathrm{B}}$ receptor antagonism on trigeminal motoneurons does not prevent REM paralysis. $\boldsymbol{a}$, EEG and EMG traces showing that $\mathrm{GABA}_{\mathrm{B}}$ receptor blockade by CGP52432 perfusion $(0.2 \mathrm{~mm})$ at the trigeminal motor pool causes robust increases in masseter activity during both waking and NREM sleep, but it does not affect levels of masseter tone during REM sleep. $\boldsymbol{b}$, Group data $(n=7)$ showing that CGP52432 perfusion $(0.01-0.2 \mathrm{~mm}$ ) heightens masseter EMG activity during waking and NREM sleep, but it does not prevent REM atonia. ${ }^{*} p<0.004$. All values are mean \pm SEM.

profile within four frequency bands. The band limits used were delta $(\delta)$ : $0.48-4 \mathrm{~Hz}$; theta $(\theta): 4.25-8 \mathrm{~Hz}$; alpha $(\alpha): 8.25-15 \mathrm{~Hz}$; beta $(\beta)$ : $15.25-35 \mathrm{~Hz}$. A mean EEG spectrum profile was obtained for each epoch and then, to minimize nonspecific differences in absolute power between individuals, EEG power in each frequency bin was expressed as a percentage of the total EEG power in the epoch. The spectral profiles of each behavioral state were then compared between treatments.

Statistical analyses

All statistical analyses were performed using Sigmastat (SPSS Inc.) and applied a critical two-tailed $\alpha$ value of $p<0.05$. All comparisons made between baseline and drug treatments were determined using ANOVA with repeated measures (RM-ANOVA) and post hoc comparisons were performed using a Student-Newman-Keuls (SNK) test. Comparisons for the microinjection experiments (i.e., drug treatments versus aCSF) were made using $t$ tests. All data are expressed as mean \pm SEM.

\section{Results}

Drug manipulations affect trigeminal motoneuron behavior Our first aim was to show that receptor manipulations target motoneurons in the trigeminal nucleus. First, we showed that all probes were located in the left trigeminal motor pool (Fig. $1 a, b$ ) and then we showed that drug manipulations only influenced the activity of the muscle (i.e., left masseter) innervated by these cells. Drug manipulations at the left trigeminal motor pool never influenced the activity of right masseter or neck muscles (Fig. $1 c, d$ ). Probe insertion into the left motor pool caused an immediate, but transient $(<1 \mathrm{~min})$, activation of only left masseter muscle tone (paired $t$ test, $t_{(4)}=$ 3.022, $p=0.039$; Fig. $1 c$ ). Neither right masseter (paired $t$ test, $t_{(4)}=0.152, p=0.887$ ) nor neck muscle activity (paired $t$ test, $t_{(4)}=$ $1.265, p=0.275$; data not shown) were affected by this intervention, suggesting that these interventions selectively targeted trigeminal motoneurons in the left motor pool.

To confirm that applied drugs affect motoneurons in the targeted motor pool, we perfused AMPA at the end of each experiment. AMPA triggered a robust motoneuron excitation that resulted in rapid and forceful activation of only left masseter EMG tone (paired $t$ test, $t_{(6)}=3.231$, $p=0.018$ ), neither right masseter (paired $t$ test, $\left.t_{(6)}=1.082, p=0.321\right)$ nor neck muscle activity (paired $t$ test, $t_{(6)}=0.042$, $p=0.968$; data not shown) were affected (Fig. 1d). This finding shows that applied drugs targeted motoneurons in only the left motor pool, which themselves remained viable throughout experiments. It also confirms that probes remained functional during the course of experimental interventions.

\section{Drug manipulations have negligible effects on REM-generating circuits} Although drug application targets motoneurons, we wanted to verify that cells bordering the trigeminal motor pool remained unaffected. The sublaterodorsal nucleus (SLD) sits beside the trigeminal motor pool (0.1-0.2 mm dorsomedial) and controls REM sleep (Boissard et al., 2002; Lu et al., 2006). Previous studies show that REM sleep is influenced by $\mathrm{GABA}_{\mathrm{A}}$ receptor antagonism at the SLD (Boissard et al., 2002; Pollock and Mistlberger, 2003; Sanford et al., 2003). Importantly, we found that antagonism of $\mathrm{GABA}_{\mathrm{A}}, \mathrm{GABA}_{\mathrm{B}}$ and glycine receptors at the trigeminal motor pool reversed REM masseter muscle paralysis (Fig. 2a), but it had no effect on REM sleep expression (REM sleep amount: baseline vs drug, $\mathrm{SNK}, q=0.215, p=0.879$; Fig. $2 b$ ). Blockade of only $\mathrm{GABA}_{\mathrm{A}}$ and glycine receptors also had no effect on REM sleep expression (REM amount: baseline vs drug, SNK, $q=0.760$, $p=0.853$; Fig. $2 b$ ). EEG spectral power during REM sleep was also unaffected by pharmacological interventions (RM ANOVA, $F_{(3,9)}=$ $1.336 p=0.232$; Fig. $2 c$ ). These findings show that changes in REM sleep muscle tone are not caused by indirect modulation of REMgenerating SLD circuits, rather they result from direct manipulation of motoneurons themselves. Our results therefore document the transmitter and receptor mechanisms responsible for controlling trigeminal motoneurons and masseter muscles in natural REM sleep.

Neither metabotropic $\mathrm{GABA}_{\mathrm{B}}$ nor ionotropic $\mathrm{GABA}_{\mathrm{A}} /$ glycine receptor-mediated inhibition themselves can trigger REM paralysis

It is unknown whether metabotropic $\mathrm{GABA}_{\mathrm{B}}$ receptors modulate motoneuron physiology during natural motor behaviors. We 
a
Baseline

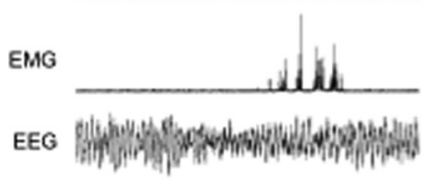

b

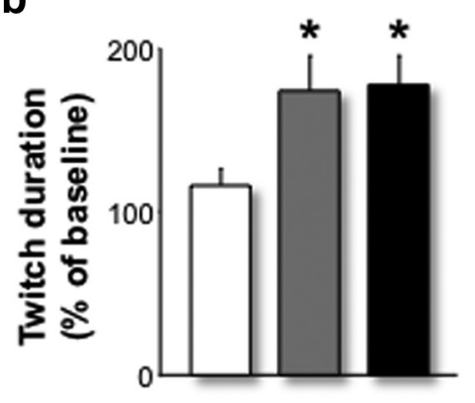

$$
\text { GABA }_{B}
$$
Antagonism

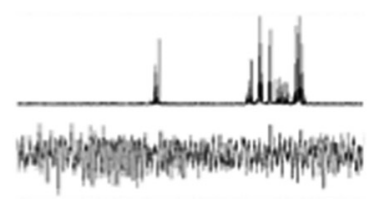

GABA $_{A} /$ Glycine Antagonism

\section{GABA $_{B} /$ GABA $_{A} /$ Glycine Antagonism}

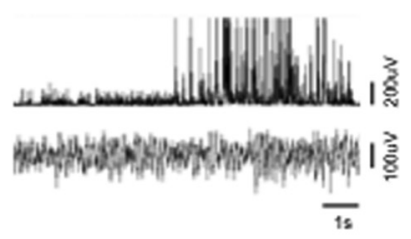

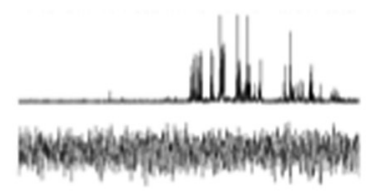

d
C

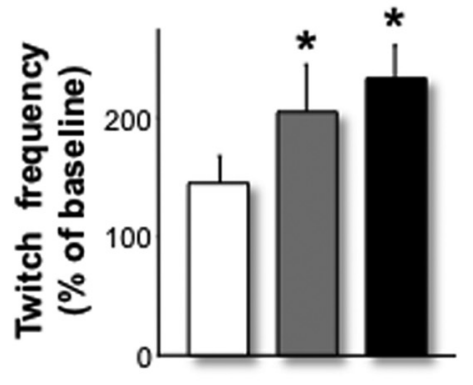

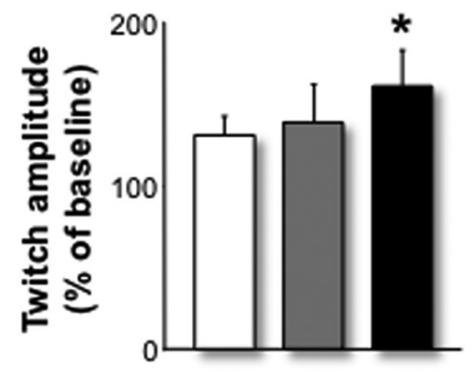

\section{$\mathrm{GABA}_{\mathrm{B}}$ Antagonism \\ - $\mathrm{GABA}_{\mathrm{B}} / \mathrm{GABA}_{\mathrm{A}} / \mathrm{Glycine}$ Antagonism}

Figure 5. Ionotropic $\mathrm{GABA}_{\mathrm{A}} /$ glycine receptor-mediated inhibition functions to suppress REM muscle twitches. $\boldsymbol{a}, \mathrm{EMG}$ and EEG traces illustrating how masseter muscle twitches during REM sleep are affected by antagonism of $G_{A B A}\left(0.2 \mathrm{~mm} \mathrm{CGP52432),GABA_{A } / g l y c i n e ~ ( 0 . 1 ~ m m ~ b i c u c u l l i n e / s t r y c h n i n e ) ~ a n d ~} G_{A B A} / G_{A B A} / g l y c i n e ~(0.2 \mathrm{~mm}\right.$ CGP52432 and $0.1 \mathrm{~mm}$ bicuculline/strychnine) receptors at the trigeminal motor pool. $\boldsymbol{b}-\boldsymbol{d}$, Group data $(n=14)$ demonstrating how metabotropic, ionotropic, and combined metabotropic/ionotropic receptor blockade on trigeminal motoneurons affects the duration $(\boldsymbol{b})$, frequency $(\boldsymbol{c})$ and amplitude $(\boldsymbol{d})$ of REM muscle twitches. ${ }^{*} p<0.05$. All values are mean \pm SEM.

found that activating $\mathrm{GABA}_{\mathrm{B}}$ receptors (by baclofen) on trigeminal motoneurons reduced waking masseter muscle tone by $78 \pm$ $5 \%$ (baseline vs baclofen; paired $t$ test, $t_{(4)}=3.960, p=0.017$; Fig. $3 a, b)$, indicating that receptor activation influences motoneuron behavior. However, $\mathrm{GABA}_{\mathrm{B}}$ receptor agonism did not trigger complete muscle paralysis since waking masseter tone remained twofold above normal REM sleep levels (baclofen during waking: $1.1 \pm 0.1$ a.u. vs baseline REM: $0.5 \pm 0.05$ a.u.; $t$ test, $t_{(18)}=4.431$, $p<0.001$; Fig. $3 b$ ). This finding suggests that $\mathrm{GABA}_{\mathrm{B}}$ receptor activation alone is incapable of inducing REM sleep muscle paralysis.

It is unknown whether metabotropic $\mathrm{GABA}_{\mathrm{B}}$ receptormediated inhibition underlies the motoneuron hyperpolarization that causes REM paralysis (Okabe et al., 1994; Brooks and Peever, 2008b). Therefore, we determined whether REM motor paralysis could be prevented by antagonizing $\mathrm{GABA}_{\mathrm{B}}$ receptors (using CGP52432) on motoneurons. CGP52432 application heightened masseter tone during both waking (RM ANOVA, $\left.F_{(5,4)}=3.147, p=0.037\right)$ and NREM sleep (RM ANOVA, $F_{(5,4)}=$ $3.052, p=0.041$; Fig. 4 ), suggesting that an endogenous GABA drive functions to inhibit motoneurons during these states by a $\mathrm{GABA}_{\mathrm{B}}$ receptor mechanism. But surprisingly, $\mathrm{GABA}_{\mathrm{B}}$ receptor antagonism had no effect on masseter muscle tone during REM sleep (RM ANOVA, $\left.F_{(5,4)}=1.521, p=0.234\right)$. Specifically, it had no effect on either masseter paralysis (SNK, $q=0.901, p=0.528$ ) or REM muscle twitch activity (baseline vs CGP52432; duration: SNK, $q=0.722, p=0.613$; frequency: SNK, $q=1.551, p=0.280$; amplitude: SNK, $q=1.852, p=0.198$; Fig. 5), suggesting that $\mathrm{GABA}_{\mathrm{B}}$ receptor-mediated inhibition alone plays a trivial role in REM motor control. This finding also suggests that a residual inhibitory drive must continue to hyperpolarize motoneurons and cause REM paralysis.

However, we show that this residual inhibition is not mediated by ionotropic $\mathrm{GABA}_{\mathrm{A}}$ and glycine receptors because antag- onizing them has no effect on REM atonia. We found that ionotropic receptor antagonism increased masseter tone during both waking (SNK, $q=10.258, p<0.001$ ) and NREM sleep (SNK, $q=7.751, p<0.05$ ), suggesting that motoneurons are inhibited during these states (Fig. 6). Receptor antagonism also triggered marked increases in the size (SNK, $q=4.576, p=$ 0.007 ) and frequency (SNK, $q=5.483, p=0.001$ ) of muscle twitches during REM sleep (Fig. 5), demonstrating that an inhibitory drive is present during REM sleep and that it functions to suppress muscle twitches. This finding is consistent with intracellular recordings, which show that motoneurons are maximally inhibited when REM muscle twitches occur (Chase and Morales, 1983; Brooks and Peever, 2008b). However, we show that GABA and glycine receptor antagonism on trigeminal motoneurons had no effect on REM masseter paralysis (SNK, $q=2.147, p=0.294$; Figs. 6, 7). In fact, removal of only $\mathrm{GABA}_{\mathrm{A}}$ and glycine receptormediated inhibition still allowed the normal drop in basal muscle tone from NREM to REM sleep (Figs. $6 a, 7 d$ ). These observations indicate that an additional, but unidentified mechanism, continues to inhibit motoneurons during REM sleep. To identify this mechanism we simultaneously antagonized both metabotropic $\mathrm{GABA}_{\mathrm{B}}$ and ionotropic $\mathrm{GABA}_{\mathrm{A}} /$ glycine receptors at the trigeminal motor pool during REM sleep.

Blockade of $\mathrm{GABA}_{B}, \mathrm{GABA}_{\mathrm{A}}$, and glycine receptors prevents REM motor paralysis

Metabotropic and ionotropic receptor-mediated mechanisms can act synergistically to affect neuron function (Liu et al., 2000; Lee et al., 2002; Balasubramanian et al., 2004). Therefore, we hypothesized that REM motor inhibition may be driven by mechanisms that require both metabotropic $\mathrm{GABA}_{\mathrm{B}}$ and ionotropic $\mathrm{GABA}_{\mathrm{A}} /$ glycine receptors. To test this hypothesis we simultaneously antagonized $\mathrm{GABA}_{\mathrm{B}}, \mathrm{GABA}_{\mathrm{A}}$ and glycine receptors 
a GABA $_{A} /$ Glycine Antagonism

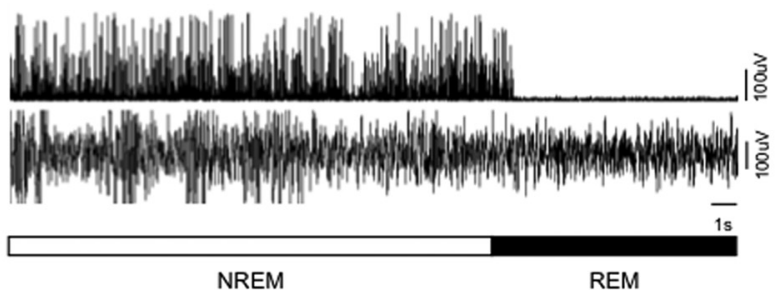

b

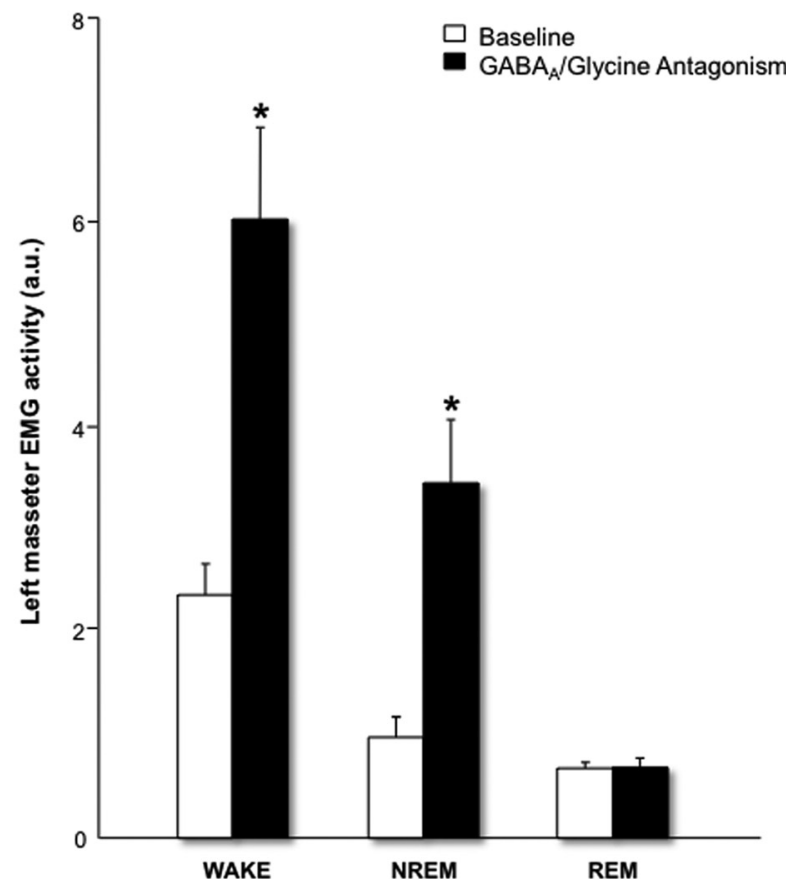

Figure 6. $\mathrm{GABA}_{\mathrm{A}}$ and glycine receptor antagonism increases masseter tone during waking and NREM sleep, but it does not prevent REM atonia. $\boldsymbol{a}$, An EMG and EEG trace showing the abrupt loss of masseter tone on entrance into REM despite continued antagonism of $\mathrm{GABA}_{A}$ / glycine receptors. $\boldsymbol{b}$, Group data $(n=14)$ showing that bicuculline and strychnine perfusion (0.1 mm for each) onto trigeminal motoneurons increases masseter EMG activity during both waking and NREM sleep. However, this same intervention has no affect on basal levels of muscle tone during REM sleep. ${ }^{*} p<0.001$. All values are mean \pm SEM.

to determine whether this intervention could prevent REM paralysis. We found that receptor antagonism on trigeminal motoneurons not only increased masseter tone during waking and NREM sleep (waking: SNK, $q=8.616, p<0.001$; NREM: SNK, $q=7.246, p<0.05$; Fig. 8), it also triggered a potent activation of masseter tone during REM sleep (Figs. 7, 8). Specifically, we found that perfusion of CGP52432 (0.2 mM) and bicuculline/ strychnine ( $0.1 \mathrm{~mm}$ for each) onto trigeminal motoneurons reversed motor paralysis by triggering a $105 \pm 30 \%$ increase in basal levels of masseter tone during REM sleep (SNK, $q=5.237$, $p=0.004$; Figs. 7, 8). In fact, when all 3 receptors were antagonized masseter muscle tone increased to levels observed during normal NREM sleep (NREM baseline vs REM drug; paired $t$ test, $t_{(13)}=1.929, p=0.076$; Fig. $7 c$ ). Despite the reversal of REM atonia brief periods of low masseter tone intermittently punctuated REM periods (Fig. 7a). This effect is in sharp contrast to blockade of only $\mathrm{GABA}_{\mathrm{A}}$ and glycine receptors, which had no influence on REM atonia (Figs. 6, 7, 8). Together, these findings suggest that REM paralysis is triggered when motoneurons are inhibited by concomitant activation of both metabotropic $\mathrm{GABA}_{\mathrm{B}}$ and ionotropic $\mathrm{GABA}_{\mathrm{A}} /$ glycine receptors.
However, our results suggest that reduced motoneuron excitation also contributes to REM paralysis. Although trigeminal motoneurons were cutoff from GABA and glycine receptormediated inhibition, REM muscle tone still remained below normal waking levels (post-REM waking during baseline vs REM drug; paired $t$ test, $t_{(13)}=3542, p=0.0036$; Fig. $7 c$ ). This observation infers that loss of wake-active excitatory drives-likely stemming from glutamate, noradrenaline, hypocretin/orexin and dopamine sources (Peever et al., 2003; Fenik et al., 2005; Burgess et al., 2008; Schwarz et al., 2008; Schwarz and Peever, 2011) — also functions to reduce motoneuron and muscle activity during REM sleep.

Activation of both metabotropic $\mathrm{GABA}_{\mathrm{B}}$ and iontotropic $\mathrm{GABA}_{\mathrm{A}} /$ glycine receptors on motoneurons is required for triggering REM sleep paralysis

In the preceding experiments we perfused (via reverse-microdialysis) GABA and glycine receptor antagonists onto trigeminal motoneurons for 2-4 h, which could cause receptor desensitization (Jones and Westbrook, 1995; Pitt et al., 2008; Bright et al., 2011) and thus insufficient receptor antagonism. To address this concern we increased antagonist concentrations (from 0.1 to $0.3 \mathrm{~mm}$ ) and applied them in a single bolus (via microinjection, $0.2 \mu \mathrm{l}$ ) only during REM sleep. Despite this additional precaution, we found that REM masseter paralysis remained completely intact when $\mathrm{GABA}_{\mathrm{A}}$ and glycine receptors on motoneurons were antagonized $\left(\mathrm{aCSF}_{(n=6)} \mathrm{vs}\right.$ $\operatorname{drug}_{(n=12)}$; $t$ test, $t_{(16)}=1.593, p=0.131$; Fig. 9). However, this intervention triggered potent increases in the frequency, duration and amplitude of REM sleep muscle twitches $(p<$ 0.05 for each variable; data not shown). Because intracellular studies show that motoneurons are maximally hyperpolarized during REM muscle twitches (Chase and Morales, 1983) and because $\mathrm{GABA}_{\mathrm{A}}$ and glycine receptor antagonism markedly increase twitch activity (Brooks and Peever, 2008b), we contend that these receptors were fully antagonized. We conclude that neither $\mathrm{GABA}_{\mathrm{A}}$ nor glycine receptor-mediated inhibition is sufficient for generating REM paralysis.

Finally, we confirmed that motoneurons are only released from REM inhibition when $\mathrm{GABA}_{\mathrm{B}}, \mathrm{GABA}_{\mathrm{A}}$ and glycine receptors are simultaneously antagonized. We did this by microinjecting CGP52432 (0.6 mM) and bicuculline/strychnine $(0.3 \mathrm{~mm}$ of each) at the trigeminal motor pool only during individual REM sleep episodes. We found that REM paralysis was rapidly overridden when both metabotropic $\mathrm{GABA}_{\mathrm{B}}$ and ionotropic $\mathrm{GABA}_{\mathrm{A}} /$ glycine receptors were blocked on trigeminal motoneurons $\left(\operatorname{aCSF}_{(n=6)} \operatorname{vs~drug}_{(n=12)} ; t\right.$ test, $t_{(17)}=3.400, p=0.003$; Fig. 9). This result is consistent with microdialysis experiments (Figs. 7, 8 ) and confirms our findings that REM paralysis is only reversed when motoneurons are cutoff from both metabotropic $\mathrm{GABA}_{\mathrm{B}}$ and ionotropic $\mathrm{GABA}_{\mathrm{A}}$ /glycine inhibition.

\section{Discussion}

Our results identify the transmitter and receptor mechanisms responsible for REM sleep paralysis. We show GABA and glycine inhibition causes motor paralysis by switching-off motoneurons during REM sleep. This drive inhibits motoneurons by activating both metabotropic $\mathrm{GABA}_{\mathrm{B}}$ and ionotropic $\mathrm{GABA}_{\mathrm{A}} /$ glycine receptors. REM motor inhibition is only prevented when motoneurons are cutoff from all sources of GABA and glycine transmission. No single form of receptor-mediated inhibition is capable of triggering REM paralysis. Current results therefore 
advance our understanding of the synaptic mechanisms underlying REM sleep paralysis.

\section{Technical considerations}

Somatic motor pools contain both motoneurons and interneurons (Moriyama, 1987; Nozaki et al., 1993). Therefore, a potential technical caveat is that our drug manipulations at the trigeminal motor pool influenced REM atonia by affecting interneuron function. However, current and previous results (Brooks and Peever, 2008b; Burgess et al., 2008; Schwarz et al., 2008) suggest that interneuron activity was negligibly affected by experimental manipulations. For example, we showed that drug interventions at the left motor pool only influenced left masseter muscle tone, they never affected right masseter tone (Figs. 1, 3). If changes in REM sleep atonia were in fact mediated by interneurons then both left and right masseter muscle tone would be affected because interneurons synaptically control motoneurons in both left and right motor pools (Ter Horst et al., 1990; McDavid et al., 2006). Accordingly, we conclude that drug interventions at the trigeminal motor pool predominantly affect motoneurons and therefore suggest that GABA and glycine receptor manipulations impact REM sleep paralysis by directly impacting trigeminal motoneuron function.

\section{Multiple mechanisms mediate REM sleep paralysis}

Our findings are important because they refute the long-standing hypothesis that a one-transmitter, one-receptor phenomenon is responsible for REM paralysis (Chase, 2008; Soja, 2008). In fact, we find no evidence to support the theory that glycine inhibition is single-handedly responsible for REM sleep paralysis. Our results clearly show that both GABA and glycine transmission are critical for normal motor control in REM sleep. Specifically, we show that metabotropic $\mathrm{GABA}_{\mathrm{B}}$ and ionotropic $\mathrm{GABA}_{\mathrm{A}} /$ glycine receptor-mediated inhibition are required for generating $R E M$ motor paralysis.

However, our results support the original concept that REM motor paralysis is caused by hyperpolarization of motoneurons (Nakamura et al., 1978). In fact, we show that an extraordinarily powerful GABA and glycine drive onto motoneurons is switched-on specifically during REM sleep. This inhibitory drive is far more pervasive than the relatively weak drive present during NREM sleep, which is easily blocked by inactivating either GABA or glycine receptors (Morrison et al., 2003; Brooks and Peever, 2008b, 2011). By comparison, REM motor inhibition is only rendered ineffective when motoneurons are completely deprived of both metabotropic $\mathrm{GABA}_{B}$ and $\mathrm{GABA}_{\mathrm{A}} /$ glycine receptor-mediated inhibition.

Metabotropic and ionotropic receptor activation could cause motoneuron inhibition and REM paralysis in a numbers of ways. Straightforward summation of long-lasting $\mathrm{GABA}_{\mathrm{B}}$ and short-lasting $\mathrm{GABA}_{\mathrm{A}}$ /glycine receptor-driven IPSPs could generate motor atonia by hyperpolarizing motoneurons.

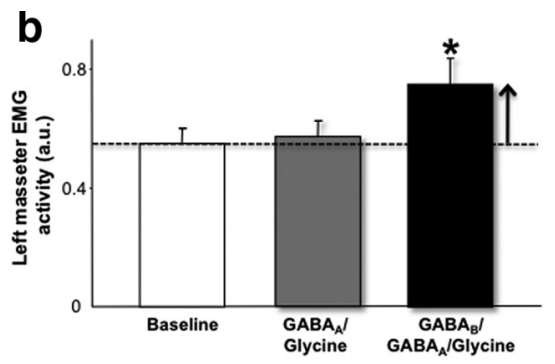

d

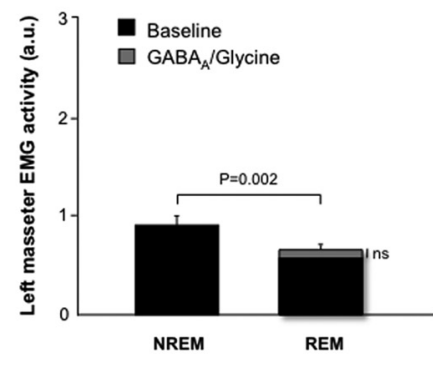

Figure 7. Activation of both metabotropic $\mathrm{GABA}_{B}$ and ionotropic $\mathrm{GABA}_{\mathrm{A}} / \mathrm{glycine} \mathrm{receptors} \mathrm{is} \mathrm{required} \mathrm{for} \mathrm{REM} \mathrm{sleep} \mathrm{paralysis.} \boldsymbol{a}$,

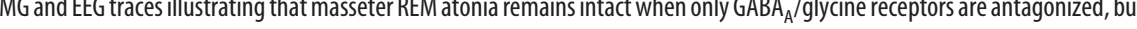

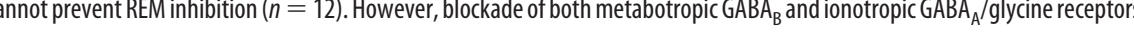
in masseter tone when NREM sleep is exited and REM sleep is entered despite continued ionotropic receptor blockade. * $p<$

However, motoneuron inhibition could also result from dynamic interactions between metabotropic and ionotropic receptors (Obrietan and van den Pol, 1998; O’Brien et al., 2004). Synergy between metabotropic and ionotropic receptor function is a well documented phenomenon in neuroscience, particularly for glutamatergic receptors. But dynamic interaction between $\mathrm{GABA}_{\mathrm{B}}, \mathrm{GABA}_{\mathrm{A}}$ and glycine receptors is also evident. For example, coactivation of $\mathrm{GABA}_{\mathrm{B}}$ and $\mathrm{GABA}_{\mathrm{A}}$ receptors produces more hyperpolarization than predicted by summation alone (Li et al., 2010) and cross talk between $\mathrm{GABA}_{\mathrm{B}}$ and ionotropic $\mathrm{GABA}_{\mathrm{A}} /$ glycine receptors affects inhibition by second-messenger and receptor phosphorylation mechanisms (Kardos and Kovacs, 1991; Kardos et al., 1994; Barilà et al., 1999). It remains to be determined how GABA and glycine inhibition functions to hyperpolarize motoneurons during REM sleep.

Additional synaptic mechanisms could also influence motoneuron physiology and muscle tone during REM sleep. For example, activation of chloride channels of the cystic fibrosis transmembrane regulator (CFTR) results in motoneuron hyperpolarization in vitro (Morales et al., 2011). Modulation of the neuron-specific potassium chloride cotransporter-2 (KCC2), which enables chloride-mediated inhibition, also influences motoneuron inhibition and motor function (Hübner et al., 2001). In addition, activation of muscarinic receptors on motoneurons functions to suppress muscle tone (Liu et al., 2005). Because brainstem cholinergic neurons also regulate REM sleep (Kodama et al., 2003; McCarley, 2004; Jones, 2008) and innervate somatic motor pools then such mechanisms also could mediate REM atonia (Lydic et al., 1989). Whether any or all of these mecha- 
a $\mathrm{GABA}_{B} / \mathrm{GABA} / \mathrm{Glycine}$ Antagonism

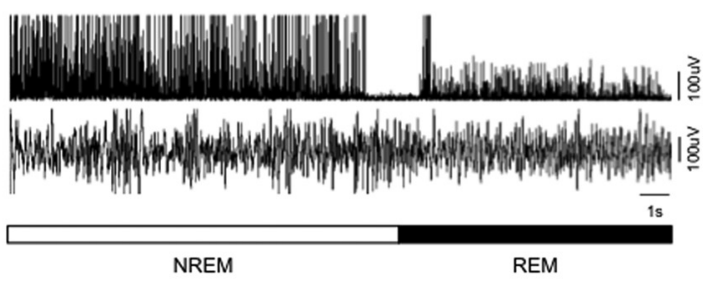

b

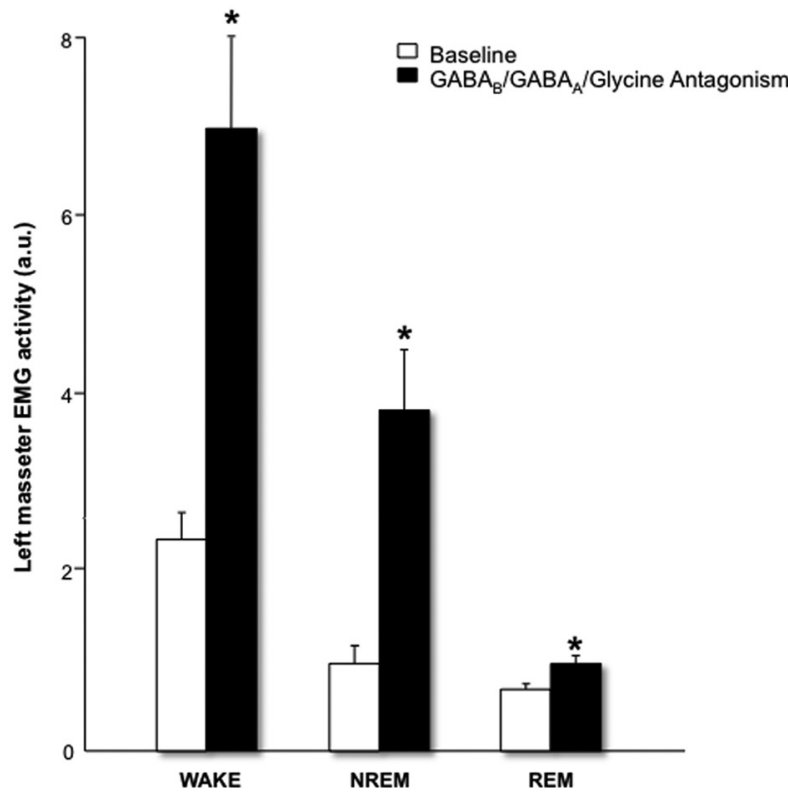

Figure 8. Antagonism of $G_{A B A_{B}}, G A B A_{A}$ and glycine increases basal masseter tone during waking, NREM and REM sleep. $\boldsymbol{a}, \mathrm{AnEMG}$ and EEG trace showing that REM masseter atonia is not triggered on entrance into REM despite when both metabotropic and ionotropic receptors are antagonized. This is in marked contrast to the complete loss of masseter tone that occurs on entrance into REM sleep when only $\mathrm{GABA}_{A} /$ glycine receptors are blocked. $\boldsymbol{b}$, Group data $(n=13)$ showing that CGP52432 $(0.2$ $\mathrm{mm}$ ) and bicuculline/strychnine perfusion ( $0.1 \mathrm{~mm}$ for each) at the trigeminal motor pool significantly increases basal levels of masseter EMG activity not only during waking and NREM sleep, but also during REM sleep. ${ }^{*} p<0.001$. All values are mean \pm SEM.

nisms control motoneuron behavior and REM paralysis remains to be determined.

REM paralysis requires both GABA and glycine inhibition

Our results reconcile a longstanding debate in biology. Two competing theories have argued that REM paralysis results from either increased glycinergic inhibition or decreased monoaminergic excitation of motoneurons. Early experiments showed that some motoneurons are hyperpolarized by glycine-sensitive IPSPs during REM sleep (Chase et al., 1989; Soja et al., 1991). However, subsequent pharmacological studies found that REM muscle paralysis was unaffected by direct antagonism of glycine receptors on motoneurons (Kubin et al., 1993; Morrison et al., 2003; Brooks and Peever, $2008 \mathrm{~b}$ ). More recently we found that REM atonia was unperturbed by the loss of function of glycine receptors in transgenic mice. Specifically, we showed that impaired glycine receptor function triggered robust REM sleep behaviors in mutant mice; however, these behaviors did not result from loss of REM sleep paralysis, but instead were caused by excessive muscle twitch activity during REM sleep (Brooks and Peever, 2011). Together, these observations refuted the claim that REM paralysis is caused by a glycine-dependent mechanism, but supported the hypothesis that it is caused by loss of motoneuron excitation. However, artificially restoring excitatory drives a

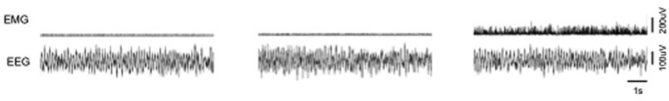

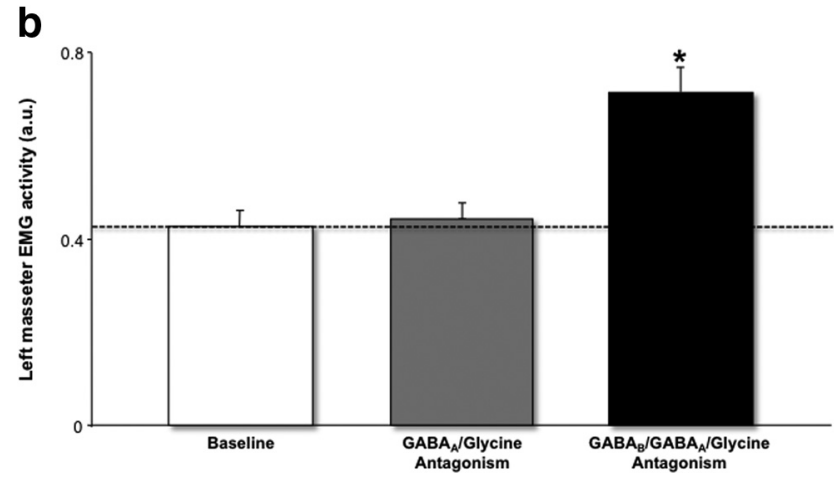

Figure 9. REM atonia is triggered by activation of both metabotropic $G A B A_{B}$ and iontotropic $\mathrm{GABA}_{\mathrm{A}} /$ glycine receptors on trigeminal motoneurons. $\boldsymbol{a}, \mathrm{EMG}$ and EEG traces showing that REM atonia is reversed when $\mathrm{GABA}_{B}, G, \mathrm{BA}_{A}$ and glycine receptors are antagonized at the trigeminal motor pool; however, atonia remains intact when only $G_{A B A_{A}}$ and glycine receptors are blocked. $\boldsymbol{b}$, Group data showing that even high concentrations of bicuculline and strychnine $(0.3$ $\mathrm{mM}$ ) applied onto trigeminal motoneurons during REM sleep cannot prevent REM inhibition $(n=12)$. However, blockade of both metabotropic $\mathrm{GABA}_{\mathrm{B}}$ and ionotropic $\mathrm{GABA}_{\mathrm{A}} /$ glycine receptors by microinjection of GGP52432 $(0.6 \mathrm{~mm})$, bicuculline and strychnine $(0.2 \mathrm{mM})$ abolishes masseter REM atonia $(n=13) .{ }^{*} p<0.003$. All values are mean \pm SEM.

onto motoneurons by exogenous neurotransmitter application (e.g., glutamate, noradrenaline, serotonin) failed to reverse REM paralysis (Jelev et al., 2001; Chan et al., 2006; Brooks and Peever, 2008b; Burgess et al., 2008). This finding provided strong support for the concept that a powerful inhibitory mechanism acts to switch-off motoneurons during REM sleep.

Our current results show that motoneuron inhibition is indeed the driving force behind REM paralysis. However, we also show that reduced motoneuron excitation acts to reinforce muscle paralysis during REM sleep. Although preventing $\mathrm{GABA}_{\mathrm{B}}$ and $\mathrm{GABA}_{\mathrm{A}} / \mathrm{gly}$ cine receptor function reversed REM paralysis, it did not restore it to waking levels. This finding suggests that motoneuron inhibition forces motoneurons and muscles to remain silent during REM sleep, but that reduced motoneuron excitation also contributes to REM atonia.

Current and previous work clearly indicate that REM paralysis results from a balance between increased motoneuron inhibition and reduced motoneuron excitation. Biochemical studies show that noradrenaline/serotonin release decreases, whereas, GABA/glycine release increases within spinal/cranial motor pools during druginduced REM sleep (Kubin et al., 1994; Lai et al., 2001; Kodama et al., 2003). Reduced excitatory drive arising from glutamate, noradrenaline, dopamine and hypocretin neurons functions to weaken motoneuron activity and reinforce REM atonia (Lai et al., 2001; Kodama et al., 2003; Peever et al., 2003; Chan et al., 2006; Burgess et al., 2008; Schwarz and Peever, 2010, 2011). It is unknown how the inhibitory and excitatory neuro-circuits establish the balance between motoneuron inhibition and disfacilitation during REM sleep. But, breakdown of either side of this system could tip the normal balance of control and result in REM motor disruption such as in REM sleep behavior disorder.

\section{Neuro-circuits underlying REM paralysis}

Potential neuro-circuits responsible for REM paralysis have been identified and mapped-out. Cells in the ventromedial medulla (VMM) and the SLD region function to promote REM paralysis (Holmes and Jones, 1994; Boissard et al., 2002, 2003; Lu et al., 
2006). Immunohistochemical studies show that cells in these regions contain GABA and glycine (Holstege, 1996; Li et al., 1996). Electrophysiological and lesion studies show these cells are REMactive and destroying them disturbs motor function during REM sleep (Schenkel and Siegel, 1989; Siegel et al., 1991; Maloney et al., 1999; Boissard et al., 2002, 2003; Lu et al., 2006; Vetrivelan et al., 2009). In addition, chemical and electrical stimulation of these REM regulating regions also triggers muscle paralysis in anesthetized animals (Lai and Siegel, 1988, 1991). Although the VMM and SLD both promote REM motor inhibition, it is unclear how they communicate with each another to initiate and maintain REM paralysis.

Our data reshape our understanding of REM motor control and we propose a new model that incorporates both past and present data. We suggest that REM-on GABA and glycine neurons in VMM regions trigger REM paralysis by directly inhibiting motoneurons during REM sleep (Lai and Siegel, 1988; Lu et al., 2006; Vetrivelan et al., 2009). REM paralysis can also be initiated by REM-on glutamate neurons in the SLD region (Lu et al., 2006; Clément et al., 2011; Luppi et al., 2011). These cells indirectly trigger motor atonia by activating GABA/glycine interneurons, which in turn inhibit motoneurons. However, REM sleep paralysis is ultimately triggered when GABA and glycine co-release hyperpolarizes motoneurons by simultaneously activating both metabotropic $\mathrm{GABA}_{\mathrm{B}}$ and ionotropic $\mathrm{GABA}_{\mathrm{A}} /$ glycine receptors.

Understanding the mechanisms mediating REM sleep paralysis is clinically important because they could explain the nature of REM sleep disorders such as RBD, sleep paralysis and cataplexy/narcolepsy. RBD results from loss of typical REM atonia, which allows pathological motor activation and dream enactment, which often lead to serious injuries (Mahowald and Schenck, 2005; Peever, 2011). Conversely, sleep paralysis and cataplexy result when REM atonia intrudes into wakefulness thus preventing normal behavior and movement (Siegel, 2006; Peever, 2011). Determining the mechanistic nature of REM sleep paralysis will improve our understanding and treatment of such disorders.

\section{References}

Araki T, Yamano M, Murakami T, Wanaka A, Betz H, Tohyama M (1988) Localization of glycine receptors in the rat central nervous system: an immunocytochemical analysis using monoclonal antibody. Neuroscience 25:613-624.

Balasubramanian S, Teissére JA, Raju DV, Hall RA (2004) Heterooligomerization between GABAA and $\mathrm{GABAB}$ receptors regulates GABAB receptor trafficking. J Biol Chem 279:18840-18850.

Barilà B, Cupello A, Robello M (1999) GABA(B) receptor activation protects $\mathrm{GABA}(\mathrm{A})$ receptor from cyclic AMP-dependent down-regulation in rat cerebellar granule cells. Neuroscience 93:1077-1082.

Boissard R, Gervasoni D, Schmidt MH, Barbagli B, Fort P, Luppi PH (2002) The rat ponto-medullary network responsible for paradoxical sleep onset and maintenance: a combined microinjection and functional neuroanatomical study. Eur J Neurosci 16:1959-1973.

Boissard R, Fort P, Gervasoni D, Barbagli B, Luppi PH (2003) Localization of the GABAergic and non-GABAergic neurons projecting to the sublaterodorsal nucleus and potentially gating paradoxical sleep onset. Eur J Neurosci 18:1627-1639.

Bright DP, Renzi M, Bartram J, McGee TP, MacKenzie G, Hosie AM, Farrant M, Brickley SG (2011) Profound desensitization by ambient GABA limits activation of delta-containing GABAA receptors during spillover. J Neurosci 31:753-763.

Brooks PL, Peever JH (2008a) Unraveling the mechanisms of REM sleep atonia. Sleep 31:1492-1497.

Brooks PL, Peever JH (2008b) Glycinergic and GABA(A)-mediated inhibition of somatic motoneurons does not mediate rapid eye movement sleep motor atonia. J Neurosci 28:3535-3545.

Brooks PL, Peever JH (2011) Impaired GABA and glycine transmission triggers cardinal features of rapid eye movement sleep behavior disorder in mice. J Neurosci 31:7111-7121.
Burgess CR, Tse G, Gillis L, Peever JH (2010) Dopaminergic regulation of sleep and cataplexy in a murine model of narcolepsy. Sleep 33:1295-1304.

Burgess C, Lai D, Siegel J, Peever J (2008) An endogenous glutamatergic drive onto somatic motoneurons contributes to the stereotypical pattern of muscle tone across the sleep-wake cycle. J Neurosci 28:4649-4660.

Chan E, Steenland HW, Liu H, Horner RL (2006) Endogenous excitatory drive modulating respiratory muscle activity across sleep-wake states. Am J Respir Crit Care Med 174:1264-1273.

Charles KJ, Calver AR, Jourdain S, Pangalos MN (2003) Distribution of a GABAB-like receptor protein in the rat central nervous system. Brain Res 989:135-146.

Chase MH (2008) Confirmation of the consensus that glycinergic postsynaptic inhibition is responsible for the atonia of REM sleep. Sleep 31:1487-1491.

Chase MH, Morales FR (1983) Subthreshold excitatory activity and motoneuron discharge during REM periods of active sleep. Science 221:1195-1198.

Chase MH, Morales FR (2005) Control of motoneurons during sleep. In: Principles and practice of sleep medicine, Ed 3 (Kryger MH, Roth T, Dement WC, eds), pp 154-168. Philadelphia: W.B. Saunders.

Chase MH, Soja PJ, Morales FR (1989) Evidence that glycine mediates the postsynaptic potentials that inhibit lumbar motoneurons during the atonia of active sleep. J Neurosci 9:743-751.

Chéry N, De Koninck Y (2000) GABA(B) receptors are the first target of released GABA at lamina I inhibitory synapses in the adult rat spinal cord. J Neurophysiol 84:1006-1011.

Clément O, Sapin E, Bérod A, Fort P, Luppi PH (2011) Evidence that neurons of the sublaterodorsal tegmental nucleus triggering paradoxical (REM) sleep are glutamatergic. Sleep 34:419-423.

Di Chiara G (1990) In-vivo brain dialysis of neurotransmitters. Trends Pharmacol Sci 11:116-121.

Fedele E, Varnier G, Raiteri M (1997) In vivo microdialysis study of $\mathrm{GABA}(\mathrm{A})$ and $\mathrm{GABA}(\mathrm{B})$ receptors modulating the glutamate receptor/ $\mathrm{NO} /$ cyclic GMP pathway in the rat hippocampus. Neuropharmacology 36:1405-1415.

Fenik VB, Davies RO, Kubin L (2005) REM sleep-like atonia of hypoglossal (XII) motoneurons is caused by loss of noradrenergic and serotonergic inputs. Am J Respir Crit Care Med 172:1322-1330.

Holmes CJ, Jones BE (1994) Importance of cholinergic, GABAergic, serotonergic and other neurons in the medial medullary reticular-formation for sleep-wake states studied by cytotoxic lesions in the cat. Neuroscience 62:1179-1200.

Holstege G (1996) The somatic motor system. Prog Brain Res 107:9-26.

Hübner CA, Stein V, Hermans-Borgmeyer I, Meyer T, Ballanyi K, Jentsch T] (2001) Disruption of KCC2 reveals an essential role of K-Cl cotransport already in early synaptic inhibition. Neuron 30:515-524.

Jelev A, Sood S, Liu H, Nolan P, Horner RL (2001) Microdialysis perfusion of 5-HT into hypoglossal motor nucleus differentially modulates genioglossus activity across natural sleep-wake states in rats. J Physiol 532:467-481.

Jones BE (2008) Modulation of cortical activation and behavioral arousal by cholinergic and orexinergic systems. Ann N Y Acad Sci 1129:26-34.

Jones MV, Westbrook GL (1995) Desensitized states prolong GABAA channel responses to brief agonist pulses. Neuron 15:181-191.

Jouvet M (1967) The states of sleep. Sci Am 216:62-68 passim.

Kardos J, Kovacs I (1991) Binding interaction of gamma aminobutyric acid A and B receptors in cell culture. Neuroreport 2:541-543.

Kardos J, Elster L, Damgaard I, Krogsgaard-Larsen P, Schousboe A (1994) Role of $\mathrm{GABA}(\mathrm{B})$ receptors in intracellular $\mathrm{Ca} 2+$ homeostasis and possible interaction between $\mathrm{GABA}(\mathrm{A})$ and $\mathrm{GABA}(\mathrm{B})$ receptors in regulation of transmitter release in cerebellar granule neurons. J Neurosci Res 39:646-655.

Kodama T, Lai YY, Siegel JM (1998) Enhanced glutamate release during REM sleep in the rostromedial medulla as measured by in vivo microdialysis. Brain Res 780:178-181.

Kodama T, Lai YY, Siegel JM (2003) Changes in inhibitory amino acid release linked to pontine-induced atonia: an in vivo microdialysis study. J Neurosci 23:1548-1554.

Kubin L, Kimura H, Tojima H, Davies RO, Pack AI (1993) Suppression of hypoglossal motoneurons during the carbachol-induced atonia of REM sleep is not caused by fast synaptic inhibition. Brain Res 611:300-312.

Kubin L, Reignier C, Tojima H, Taguchi O, Pack AI, Davies RO (1994) 
Changes in serotonin level in the hypoglossal nucleus region during carbachol-induced atonia. Brain Res 645:291-302.

Lai YY, Siegel JM (1988) Medullary regions mediating atonia. J Neurosci 8:4790-4796.

Lai YY, Siegel JM (1991) Pontomedullary glutamate receptors mediating locomotion and muscle tone suppression. J Neurosci 11:2931-2937.

Lai YY, Kodama T, Siegel JM (2001) Changes in monoamine release in the ventral horn and hypoglossal nucleus linked to pontine inhibition of muscle tone: an in vivo microdialysis study. J Neurosci 21:7384-7391.

Lalley PM (1986) Effects of baclofen and gamma-aminobutyric-acid on different types of medullary respiratory neurons. Brain Res 376:392-395.

Lee FJ, Xue S, Pei L, Vukusic B, Chéry N, Wang Y, Wang YT, Niznik HB, Yu XM, Liu F (2002) Dual regulation of NMDA receptor functions by direct protein-protein interactions with the dopamine D1 receptor. Cell 111:219-230.

Li C, Xu B, Wang WW, Yu XJ, Zhu J, Yu HM, Han D, Pei DS, Zhang GY (2010) Coactivation of GABA receptors inhibits the JNK3 apoptotic pathway via disassembly of GluR6-PSD-95-MLK3 signaling module in KA-induced seizure. Epilepsia 51:391-403.

Li YQ, Takada M, Kaneko T, Mizuno N (1996) GABAergic and glycinergic neurons projecting to the trigeminal motor nucleus: a double labeling study in the rat. J Comp Neurol 373:498-510.

Liu F, Wan Q, Pristupa ZB, Yu XM, Wang YT, Niznik HB (2000) Direct protein-protein coupling enables cross-talk between dopamine D5 and gamma-aminobutyric acid A receptors. Nature 403:274-280.

Liu X, Sood S, Liu H, Horner RL (2005) Opposing muscarinic and nicotinic modulation of hypoglossal motor output to genioglossus muscle in rats in vivo. J Physiol 565:965-980.

Lu J, Sherman D, Devor M, Saper CB (2006) A putative flip-flop switch for control of REM sleep. Nature 441:589-594.

Luppi PH, Clément O, Sapin E, Gervasoni D, Peyron C, Léger L, Salvert D, Fort P (2011) The neuronal network responsible for paradoxical sleep and its dysfunctions causing narcolepsy and rapid eye movement (REM) behavior disorder. Sleep Med Rev 15:153-163.

Lydic R, Baghdoyan HA, Zwillich CW (1989) State-dependent hypotonia in posterior cricoarytenoid muscles of the larynx caused by cholinoceptive reticular mechanisms. FASEB J 3:1625-1631.

Mahowald MW, Schenck CH (2005) Insights from studying human sleep disorders. Nature 437:1279-1285.

Maloney KJ, Mainville L, Jones BE (1999) Differential c-Fos expression in cholinergic, monoaminergic, and GABAergic cell groups of the pontomesencephalic tegmentum after paradoxical sleep deprivation and recovery. J Neurosci 19:3057-3072.

Margeta-Mitrovic M, Mitrovic I, Riley RC, Jan LY, Basbaum AI (1999) Immunohistochemical localization of GABA(B) receptors in the rat central nervous system. J Comp Neurol 405:299-321.

Matsuki T, Nomiyama M, Takahira H, Hirashima N, Kunita S, Takahashi S, Yagami K, Kilduff TS, Bettler B, Yanagisawa M, Sakurai T (2009) Selective loss of $\mathrm{GABA}(\mathrm{B})$ receptors in orexin-producing neurons results in disrupted sleep/wakefulness architecture. Proc Natl Acad Sci U S A 106:4459-4464.

McCarley RW (2004) Mechanisms and models of REM sleep control. Arch Ital Biol 142:429-467.

McDavid S, Lund JP, Auclair F, Kolta A (2006) Morphological and immunohistochemical characterization of interneurons within the rat trigeminal motor nucleus. Neuroscience 139:1049-1059.

Morales FR, Sampogna S, Rampon C, Luppi PH, Chase MH (2006) Brainstem glycinergic neurons and their activation during active (rapid eye movement) sleep in the cat. Neuroscience 142:37-47.

Morales FR, Silveira V, Damián A, Higgie R, Pose I (2011) The possible additional role of the cystic fibrosis transmembrane regulator to motoneuron inhibition produced by glycine effects. Neuroscience 177:138-147.

Moriyama Y (1987) Rhythmical jaw movements and lateral pontomedullary reticular neurons in rats. Comp Biochem Physiol A Comp Physiol 86:7-14.

Morrison JL, Sood S, Liu H, Park E, Liu X, Nolan P, Horner RL (2003) Role of inhibitory amino acids in control of hypoglossal motor outflow to genioglossus muscle in naturally sleeping rats. J Physiol 552:975-991.

Nakamura Y, Goldberg LJ, Chandler SH, Chase MH (1978) Intracellular analysis of trigeminal motoneuron activity during sleep in the cat. Science 199:204-207.

Nozaki S, Iriki A, Nakamura Y (1993) Trigeminal premotor neurons in the bulbar parvocellular reticular formation participating in induction of rhythmical activity of trigeminal motoneurons by repetitive stimulation of the cerebral cortex in the guinea pig. J Neurophysiol 69:595-608.

O’Brien JA, Berger AJ (1999) Cotransmission of GABA and glycine to brain stem motoneurons. J Neurophysiol 82:1638-1641.

O'Brien JA, Sebe JY, Berger AJ (2004) GABA(B) modulation of GABA(A) and glycine receptor-mediated synaptic currents in hypoglossal motoneurons. Respir Physiol Neurobiol 141:35-45.

Obrietan K, van den Pol AN (1998) GABA(B) receptor-mediated inhibition of $\mathrm{GABA}(\mathrm{A})$ receptor calcium elevations in developing hypothalamic neurons. J Neurophysiol 79:1360-1370.

Okabe S, Woch G, Kubin L (1994) Role of GABAB receptors in the control of hypoglossal motoneurons in vivo. Neuroreport 5:2573-2576.

Ouyang C, Guo L, Lu Q, Xu X, Wang H (2007) Enhanced activity of GABA receptors inhibits glutamate release induced by focal cerebral ischemia in rat striatum. Neurosci Lett 420:174-178.

Paxinos G, Watson C (1998) The rat brain in stereotaxic coordinates, Ed 4. New York: Academic

Peever J (2011) Control of motoneuron function and muscle tone during REM sleep, REM sleep behavior disorder and cataplexy/narcolepsy. Arch Ital Biol 149:454-466

Peever JH, Lai YY, Siegel JM (2003) Excitatory effects of hypocretin-1 (orexin-A) in the trigeminal motor nucleus are reversed by NMDA antagonism. J Neurophysiol 89:2591-2600.

Persohn E, Malherbe P, Richards JG (1992) Comparative molecular neuroanatomy of cloned GABAA receptor subunits in the rat CNS. J Comp Neurol 326:193-216.

Pitt SJ, Sivilotti LG, Beato M (2008) High intracellular chloride slows the decay of glycinergic currents. J Neurosci 28:11454-11467.

Pollock MS, Mistlberger RE (2003) Rapid eye movement sleep induction by microinjection of the GABA-A antagonist bicuculline into the dorsal subcoeruleus area of the rat. Brain Res 962:68-77.

Rampon C, Peyron C, Petit JM, Fort P, Gervasoni D, Luppi PH (1996) Origin of the glycinergic innervation of the rat trigeminal motor nucleus. Neuroreport 7:3081-3085.

Sanford LD, Tang X, Xiao J, Ross RJ, Morrison AR (2003) GABAergic regulation of REM sleep in reticularis pontis oralis and caudalis in rats. J Neurophysiol 90:938-945.

Schenck CH, Mahowald MW (2002) REM sleep behavior disorder: clinical, developmental, and neuroscience perspectives 16 years after its formal identification in SLEEP. Sleep 25:120-138.

Schenkel E, Siegel JM (1989) REM-sleep without atonia after lesions of the medial medulla. Neurosci Lett 98:159-165.

Schwarz PB, Peever JH (2010) Noradrenergic control of trigeminal motoneurons in sleep: relevance to sleep apnea. Adv Exp Med Biol 669:281-284.

Schwarz PB, Peever JH (2011) Dopamine triggers skeletal muscle tone by activating D1-like receptors on somatic motoneurons. J Neurophysiol 106:1299-1309.

Schwarz PB, Yee N, Mir S, Peever JH (2008) Noradrenaline triggers muscle tone by amplifying glutamate-driven excitation of somatic motoneurones in anaesthetized rats. J Physiol 586:5787-5802.

Siegel JM (2006) The stuff dreams are made of: anatomical substrates of REM sleep. Nat Neurosci 9:721-722.

Siegel JM, Nienhuis R, Fahringer HM, Paul R, Shiromani P, Dement WC, Mignot E, Chiu C (1991) Neuronal activity in narcolepsy: identification of cataplexy-related cells in the medial medulla. Science 252:1315-1318.

Soja PJ (2008) Glycine-mediated postsynaptic inhibition is responsible for REM sleep atonia. Sleep 31:1483-1486.

Soja PJ, López-Rodríguez F, Morales FR, Chase MH (1991) The postsynaptic inhibitory control of lumbar motoneurons during the atonia of active sleep: effect of strychnine on motoneuron properties. J Neurosci 11:2804-2811.

Ter Horst GJ, Copray JC, Van Willigen JD, Liem RS (1990) Contralateral projections of cells in the motor trigeminal nucleus of the rat. Neurosci Lett 113:260-266.

Vetrivelan R, Fuller PM, Tong Q, Lu J (2009) Medullary circuitry regulating rapid eye movement sleep and motor atonia. J Neurosci 29:9361-9369.

Westerink BH, Kwint HF, deVries JB (1996) The pharmacology of mesolimbic dopamine neurons: a dual-probe microdialysis study in the ventral tegmental area and nucleus accumbens of the rat brain. J Neurosci 16:2605-2611. 